\title{
ANALISIS KEGAGALAN PEMBERDAYAAN USAHA INDUSTRI ROTI DI GAMPONG TINGKEUM MANYANG KECAMATAN KUTA BLANG KABUPATEN BIREUEN
}

\author{
Desy Suryanti, Ti Aisyah *), Ahmad Yani \\ ${ }^{*}$ Program Studi Administrasi Publik Universitas Malikussaleh, tiaisyah@ unimal.ac.id
}

\begin{abstract}
The economic wheels in Gampong Tingkeum Manyang are driven by the home industri sector. This reality encourages Dinas Tenaga Kerja, Transmigrasi, dan Perindustrian Kabupaten Bireuen to carry out community empowerment activities. One of the empowered businesses is the biscuit industri. Peanut and coconut biscuits as superior products from the region have been marketed to several regions in Aceh. However, around 2016 to 2019 there was a decline in production. The decline was due to lack of capital, competition, and low productivity. This study aims to determine the strategy in empowering the biscuit industri undertaken by the government to explore what factors have caused the failure of the home industri business. The research approach used is a descriptive qualitative approach. The results showed that the strategies used by the Dinas Tenaga Kerja, Transmigrasi, dan Perindustrian Kabupaten Bireuen were building the capacity of the human resources of actors and supporting business capital. However, the community empowerment efforts were not sustainable so that it was less controlled in the process.
\end{abstract}

ABSTRACT

Keywords: Community Empowerment, Biscuit Industri, Tingkeum Manyang Village

\begin{abstract}
ABSTRAK
Roda ekonomi di Gampong Tingkeum Manyang digerakkan oleh sektor industri rumah tangga. Realitas ini mendorong Dinas Tenaga Kerja, Transmigrasi, dan Perindustrian Kabupaten Bireuen melaksanakan kegiatan pemberdayaan masyarakat. Salah satu usaha yang diberdayakan yaitu industri roti kering. Roti kacang dan roti kelapa sebagai produk unggulan dari daerah tersebut telah dipasarkan ke beberapa wilayah di Aceh. Namun sekitar tahun 2016 sampai 2019 terjadi penurunan produksi. Penurunan tersebut diakibatkan kekurangan modal, persaingan, dan produktivitas kerja yang rendah. Penelitian ini bertujuan mengetahui strategi dalam pemberdayaan usaha industri roti kering yang dilakukan oleh pemerintah untuk digali faktor apa yang menyebabkan kegagalan usaha industri rumah tangga tersebut. Adapun pendekatan penelitian yang digunakan yaitu pendekatan kualitatif deskriptif. Hasil penelitian menunjukkan bahwa strategi yang digunakan oleh Dinas Tenaga Kerja, Transmigrasi, dan Perindustrian Kabupaten Bireuen yaitu membangun kapasitas sumber daya manusia aktor dan pemberian modal usaha. Namun upaya pemberdayaan masyarakat yang dilakukan tidak dilakukan secara berkelanjutan sehingga kurang terkendali dalam prosesnya.
\end{abstract}

Kata Kunci: Pemberdayaan Masyarakat, Industri Roti, Gampong Tingkeum Manyang 


\section{PENDAHULUAN}

Industri kecil banyak bergerak di bidang pengolahan sehingga barang dan jasa memiliki nilai ekonomi yang lebih tinggi (Gaspersz, 2005; Stoler dalam Martisari, 2008). Kelebihan yang dimiliki oleh industri kecil adalah memperluas kesempatan kerja dan menambah pendapatan bagi banyak rumah tangga. Hal ini dimungkinkan karena industri kecil biasanya menggunakan teknologi madya dan sederhana serta bersifat padat karya (Evi, 2001; Rachmad \& Yuda, 2009).

Perkembangan industri kecil di suatu wilayah tidak selalu berarti bahwa wilayah tersebut memiliki bahan baku yang berlimpah, tetapi lebih merupakan suatu kegiatan yang menggambarkan adanya traditional skill yang dimiliki penduduknya. Usaha industri kecil perlu dikelola dengan baik dengan tujuan agar tercapai keteraturan, kelancaran, dan kelangsungan usaha serta para pekerja dapat bekerja secara efisien. Supaya industri kecil dapat berjalan lancar maka perlu diatur kegiatannya. Pengaturan yang rapi merupakan unsur yang berkaitan dalam penyelenggaraan aktivitas usaha industri kecil. Bidang-bidang usaha yang dilakukan mencakup beberapa hal diantaranya pengelolaan kemampuan, produksi, dan pemasaran.

Bekerja di industri kecil roti kering menjadi keseharian beberapa kaum perempuan di Gampong Tingkeum Manyang sejak tahun 2012. Dalam hal ini industri kecil roti kering telah menambah pendapatan sehari-hari beberapa keluarga. Secara tidak langsung usaha industri roti kering turut berkontribusi pula dalam menumbuh-kembangkan perekonomian di Kabupaten Bireuen. Oleh karena itu, Pemerintah Kabupaten Bireuen berkepentingan dalam mendorong para pelaku industri roti kering di Gampong Tingkeum Manyang meningkatkan produksi, keterampilan, dan kreativitas.

Diketahui bahwa produksi dan jumlah tenaga kerja usaha industri kecil roti kering Gampong Tingkeum Manyang hanya meningkat dari tahun 2013-2015, sementara pada tahun 2016-2019 terus mengalami penurunan. Ilustrasinya dapat dilihat pada tabel berikut:

Tabel 1. Jumlah Pekerja dan Produksi Roti Kering Gampong Tingkeum Manyang

\begin{tabular}{|c|c|c|c|}
\hline No. & Tahun & Jumlah Pekerja & Rata-Rata Produksi per Bulan \\
\hline 1 & 2013 & 4 orang & $50 \mathrm{bal}$ \\
\hline 2 & 2014 & 7 orang & $110 \mathrm{bal}$ \\
\hline 3 & 2015 & 10 orang & $175 \mathrm{bal}$ \\
\hline 4 & 2016 & 12 orang & $156 \mathrm{bal}$ \\
\hline 5 & 2017 & 9 orang & $120 \mathrm{bal}$ \\
\hline 6 & 2018 & 6 orang & $95 \mathrm{bal}$ \\
\hline 7 & 2019 & 6 orang & $95 \mathrm{bal}$ \\
\hline
\end{tabular}

Sumber: data penelitian, 2020

16 | Jurnal Ilmu Sosial dan Ilmu Politik Malikussaleh (JSPM) Volume 2 Nomor 1 Tahun 2021 
Kondisi tersebut berdampak buruk terhadap kelangsungan industri roti kering dan pendapatan yang diperoleh para pekerja. Pemerintah Kabupaten Bireuen sendiri sudah melaksanakan pemberdayaan yang menyangkut dengan sosialisasi, pembinaan, pemberian motivasi, dan pengorganisasian mengenai tata cara pengembangan usaha. Agen pemberdayaan dimotori oleh Dinas Tenaga Kerja, Transmigrasi, dan Perindustrian Kabupaten Bireuen, sementara kelompok sasaran pemberdayaan yaitu para pekerja industri roti kering di Gampong Tingkeum Manyang. Namun program dan kegiatan yang dilakukan belum mampu menyelamatkan potensi lokal industri kecil roti kering di Gampong Tingkem Manyang dari ancaman kebangkrutan. Berdasarkan latar belakang di atas, penelitian ini bermaksud menganalisa kegagalan strategi Pemerintah Daerah dalam kegiatan pemberdayaan yang telah dilaksanakan.

Ketidakoptimalan program pemberdayaan masyarakat yang dilakukan oleh Pemerintah sudah menjadi tema klasik di Indonesia. Dalam beberapa literatur sebelumnya, kegagalan juga dialami di sejumlah daerah seperti studi yang dilakukan oleh Adnan (2017) di Kabupaten Polewali Mandar. Kegagalan pemberdayaan usaha kecil dan menengah di daerah tersebut terjadi karena ketidaksiapan masyarakat dan keterbatasan sarana dan prasarana sehingga program yang dilakukan terkesan tidak emansipatoris. Kendala sumber daya manusia dan fasilitas pendukung program pemberdayaan juga dialami di Kota Lhokseumawe berdasarkan studi yang dilakukan oleh Nanda (2018). Hasil penelitian menunjukkan bahwa strategi yang digunakan oleh PT. Pupuk Iskandar Muda (PIM) dalam memberdayakan usaha kecil dan menengah di sekitar perusahaan kurang efektif karena sejumlah kendala di atas dan kurangnya pengawasan dari pihak PT. PIM sendiri.

\section{Strategi Pemberdayaan Masyarakat}

Pemberdayaan dapat dilakukan melalui tiga aras, yaitu mikro, mezzo, dan makro (Suharto, 2005). Pemberdayaan diarahkan kepada keberpihakan, pemantapan otonomi, dan modernisasi kelompok sasaran (Mardikanto \& Soebianto, 2012; Ikramatoun et. al, 2020). Beberapa strategi dapat menjadi pertimbangan untuk diterapkan dalam pemberdayaan masyarakat, seperti menciptakan iklim, memperkuat daya, dan melindungi (Usman, 2003). Intinya adalah pemberdayaan masyarakat membutuhkan pendampingan (Soetomo, 2006). Sementara beberapa prinsip dasar dalam mewujudkan masyarakat berdaya menurut Sulistiyani (2004) yaitu penyadaran, pengorganisasian, dan membangun dinamika. Sejumlah faktor mempengaruhi keberhasilan program pemberdayaan masyarakat yang terdiri dari faktor internal dan faktor eksternal (Sumodiningrat, 2003). Watson dalam Adi (2008) menyatakannya sebagai kendala yang berasal dari kepribadian individu dan kendala yang berasal dari sistem sosial. Pemerintah 
diharapkan mampu memahami faktor-faktor yang menjadi kendala pemberdayaan guna menyesuaikan kebijakan yang mungkin ditempuh dalam menjalankan program pemberdayaan masyarakat.

Pelaku industri kecil perlu diberdayakan oleh pemerintah. Pengembangan industri kecil akan membantu mengatasi masalah pengangguran karena teknologi yang digunakan adalah teknologi padat karya sehingga bisa memperbesar lapangan kerja dan kesempatan usaha, yang pada gilirannya mendorong pembangunan daerah dan kawasan pedesaan (Kuncoro, 2006). Upaya-upaya pengembangan usaha kecil yaitu melakukan pembinaan dan pengembangan usaha kecil dalam bidang produksi dan pengolahan, pemasaran, sumber daya manusia, teknologi melalui peningkatan kemampuan manajemen serta teknik produksi dan pengolahan, kemampuan perekayasaan, dan kemudahan dalam pengadaan sarana dan prasarana produksi serta pengolahan bahan baku dan kemasan (Arifah, 2011; Dewi, et al., 2015; Maisyura, et al., 2019).

\section{METODE PENELITIAN}

Lokasi penelitian yang dilakukan oleh peneliti yaitu di Gampong Tingkeum Manyang Kecamatan Kuta Blang Kabupaten Bireuen Provinsi Aceh. Pendekatan yang digunakan dalam penelitian ini adalah pendekatan kualitatif dengan tipe deskriptif yaitu pendekatan yang digunakan untuk meneliti pada kondisi objek yang alamiah (Sugiyono, 2005). Para informan adalah orangorang yang dapat memberi informasi atau data terkait dengan masalah dan fokus penelitian yang dikaji/diteliti, diantaranya Kepala Bidang Dinas Tenaga Kerja Transmigrasi dan Perindustrian Kabupaten Bireuen, Kepala Seksi Industri Kecil Menengah dan Kerajinan Dinas Tenaga Kerja, Transmigrasi dan Perindustrian Kabupaten Bireuen, Camat, Keuchik Gampong Tingkeum Manyang, pemilik industri roti kering, pekerja industri roti kering, dan masyarakat. Dalam penelitian ini teknik pengumpulan data yang digunakan adalah pengamatan, wawancara, dan dokumentasi. Data dianalisis secara kualitatif, kutipan dari hasil wawancara ditampilkan untuk mendukung analisa data yang digunakan dalam memecahkan masalah yang timbul dari penelitian sejak awal sampai selesainya pengumpulan data.

\section{HASIL DAN PEMBAHASAN}

\section{Strategi Pemerintah dalam Pemberdayaan Usaha Industri Roti Kering}

Pemerintah Kabupaten Bireuen menerapkan berbagai strategi dalam pemberdayaan usaha industri roti kering Gampong Tingkeum Manyang Kecamatan Kuta Blang Kabupaten Bireuen. Secara keseluruhan arah kebijakan terhadap pelaksanaan pemberdayaan telah dilakukan oleh 
pemerintah Kabupaten Bireuen melalui Dinas Tenaga Kerja, Transmigrasi, dan Perindustrian Kabupaten Bireuen, walaupun kelembagaan tersebut belum secara maksimal mengembangkan fungsinya sebagai wadah kegiatan pemberdayaan.

Berdasarkan hasil survei oleh pihak Dinas sendiri, usaha indutri roti kering Gampong Tingkeum Manyang pada tahun 2015 setelah diadakannya pemberdayaan mulai ada kemajuan karena jumlah produksi meningkat. Artinya pemberdayaan tersebut berdampak baik dan ilmu yang diberikan tersalurkan dengan baik. Pelaksanaan strategi pemberdayaan berpengaruh terhadap proses pelaksanaan kegiatan produksi sehingga apa yang sudah didapatkan kelompok sasaran selama pelaksanaan pemberdayaan berjalan positif. Berikut ini adalah beberapa strategi yang diterapkan oleh Dinas Tenaga Kerja, Transmigrasi, dan Perindustrian Kabupaten Bireuen:

\section{a. Pelatihan atau Pembinaan, Sosialisasi, dan Motivasi}

Pelatihan atau pembinaan dilaksanakan sebagai bekal setiap pelaku usaha untuk mendapatkan kesempatan mengembangkan usahanya sehingga dapat berlanjut dan berkembang menjadi besar, berkelanjutan, dan bermanfaat bagi masyarakat sekitar dalam peningkatan taraf ekonomi. Pelatihan atau pembinaan yang dilakukan Dinas Tenaga Kerja, Transmigrasi, dan Perindustrian Kabupaten Bireuen terkait dengan cara-cara dalam menghasilkan produk roti yang menarik dan unggul di pasaran serta memiliki daya tarik sendiri bagi konsumen dengan inovasiinovasi baru seperti membuat aneka ragam bentuk roti, rasa, maupun warna.

Secara kuantitas pelatihan telah dilaksanakan dua kali dalam kurun waktu satu tahun. Pelaksanaan pemberdayaan tersebut dilakukan dengan mengelompokkan usaha-usaha industri yang sejenis dengan usaha industri roti kering Gampong Tingkeum Manyang. Hal ini dilakukan agar mempermudah pihak dinas dalam memberikan pelatihan, sosialisasi dan sebagainya. Untuk pelaksanaannya dilakukan secara bergulir dengan jumlah peserta yang ikut dalam sekali pelatihan 15-20 orang dengan lama waktu pelatihan rata-rata sehari atau dua hari.

Materi pelatihan berkaitan dengan peningkatan kapasitas IPTEK (ilmu pengetahuan dan tekonologi) agar usaha maju dan unggul. Berkaitan dengan hal tersebut pemerintah memperkenalkan adanya teknologi baru yang efektif dan efisien dalam proses pengolahan roti kering yang dapat menghemat waktu, tenaga, atau cara kerja yang lebih cepat seperti alat penyemprot untuk pemberian warna pada roti kering. Materi pelatihan juga terkait dengan pengetahuan dalam mengembangkan usaha dan komitmen serta pola pikir atau mindset yang harus diubah demi pencapaian bisnis atau usaha yang handal serta pelaku usaha yang berwawasan.

19 | Jurnal Ilmu Sosial dan Ilmu Politik Malikussaleh (JSPM) Volume 2 Nomor 1 Tahun 2021 
Pelatihan atau pembinaan dilaksanakan guna menciptakan arah dan tujuan dalam rangka mewujudkan usaha yang maju, memiliki produk yang berkualitas, dan pemasaran yang luas seperti yang disampaikan oleh Kepala Seksi Industri Kecil Menengah dan Kerajinan Dinas Tenaga Kerja, Transmigrasi dan Perindustrian Kabupaten Bireuen berikut ini:

"Dinas dalam memberikan pelatihan terkait dengan cara-cara dalam menghasilkan produk roti yang menarik atau dengan inovasi-inovasi baru seperti roti dengan beragam bentuk, rasa, ataupun warna yang dapat menarik minat konsumen sekaligus menjadi pembeda dengan produk lain dan menjadi unggul di pasaran." (Eliya Novita, S.T, Bireuen, 16/12/2019).

Selain pelatihan dilakukan pula sosialisasi. Sosialisasi merupakan suatu proses bagaimana memperkenalkan suatu sistem kepada masyarakat sehingga menjadi dikenal dan dipahami. Sosialisasi penting dilakukan untuk memberikan pengetahuan kepada masyarakat tentang kelebihan dan keunggulan suatu produk. Dinas Tenaga Kerja, Transmigrasi, dan Perindustrian Kabupaten Bireuen mensosialisasikan pentingnya penerapan standar mutu suatu produk dan pengawasan pada berbagai kegiatan tahapan produksi sampai hasil produksi dapat diterima sesuai dengan keinginan konsumen. Proses ini penting guna menjaga mutu dan kualitas hasil produksi. Dengan demikian, sosialisasi menjadi titik awal untuk mewujudkan usaha yang mampu memenuhi keinginan konsumen agar tetap laku dan eksis di pasaran serta memberikan kepuasan semaksimal mungkin kepada pelanggan. Menurut Kepala Seksi Industri Kecil Menengah dan Kerajian Kabupaten Bireuen:

"Sosialisasi mengenai penerapan standar mutu dan pengawasan pada berbagai tahapan kegiatan produksi dan kegiatan koreksi pada tahapan pengerjaan produk, sampai hasil produksi dapat diterima sesuai dengan harapan konsumen..” (Eliya Novita, ST, Bireuen, 16/12/2019).

Dalam rangka menumbuhkembangkan usaha, motivasi menjadi suatu penggerak atau menggugah seseorang agar timbul keinginan dan kemauan untuk melakukan sesuatu sehingga dapat memperoleh hasil atau tujuan tertentu. Pemberian motivasi secara berkala kepada pelaku usaha industri roti kering Gampong Tingkeum Manyang juga diberikan sebagai dorongan untuk terus mempertahankan usaha dalam rangka mempermudah jalannya usaha dalam memproduksi roti kering.

\section{b. Peningkatan Kemampuan Finansial}

Peningkatan kemampuan finansial merupakan salah satu strategi pemerintah dalam memberdayakan usaha industri roti kering. Berdasarkan hasil wawancara terdapat penguatan 
modal yang diberikan kepada usaha indusri roti kering Gampong Tingkeum Manyang yang dapat digunakan untuk mengembangkan usaha, meningkatkan produksi, dan melengkapi sarana dan prasarana. Jumlah dana yang diberikan pada tahun 2015 sebesar Rp. 5.000.000 dengan metode pengembaliannya adalah dengan membayar cicilan per bulan terhadap keseluruhan dana yang didapatkan dengan bunga $0 \%$ dalam jangka waktu pengembalian satu tahun.

Dengan demikian peran pemerintah dalam penguatan modal usaha terhadap masyarakat khususnya yang memiliki usaha aktif seperti usaha industri roti kering Gampong Tingkeum Manyang tentu sangat membantu, dan juga diharapkan usaha yang sudah berkembang dan berjalan tersebut dapat mempertahankan kegiatan produksinya, menata sistem keuangan dengan baik untuk kesehatan dan keselamatan usaha, sistem pengelolaan dan peralatan untuk meningkatkan produktivitas, penataan sistem kerja produksi yang lebih efisien, dan sistem pengelolaan bahan baku untuk mencapai hasil yang optimal.

Modal berupa uang yang disalurkan untuk mengoptimalkan kegiatan usaha. Dalam kegiatan produksi modal memiliki peran besar, tanpa adanya modal maka suatu kegiatan atau usaha tidak dapat terlaksana sehingga penguatan modal ataupun peningkatan kemampuan finansial menjadi hal pokok dalam menggerakkan suatu proses pencapaian hasil usaha (Sufi, 2020). Semakin banyak modal yang digunakan maka semakin banyak barang yang dapat diproduksi dan semakin canggih teknologi yang digunakan untuk memproduksi barang. Terkait dengan modal usaha, salah seorang pemilik usaha industri roti kering Gampong Tingkeum Manyang mengatakan:

"Modal yang diberikan Dinas Perindustrian Kabupaten Bireuen pada tahun 2015 sebesar Rp. 5.000 .000 .... Namun sangat disayangkan pemberian modal ini tidak berkelanjutan, sehingga apabila modal tersebut habis terpakai maka tidak ada pemberian modal selanjutnya, padahal modal pada tahap selanjutnya diperlukan apabila belum balik modal yang sebelumnya." (Nurlaili, Tingkeum Manyang, 14/12/2019).

\section{c. Mempermudah Perizinan}

Pemerintah Kabupaten Bireuen juga memfasilitasi dan mempermudah masyarakat khususnya yang memiliki usaha untuk mendapatkan izin usaha indutri kecil. Usaha ini dilakukan dalam rangka mempersempit kendala struktural yang mungkin dihadapi oleh para pelaku industri kecil di Gampong Tingkeum Manyang. Selain itu, merk roti kering produksi Gampong Tingkeum Manyang sudah terdaftar/didaftarkan dengan merk Cap Segitiga.

\section{d. Peningkatan Daya Saing Produk Unggulan}

21 | Jurnal Ilmu Sosial dan Ilmu Politik Malikussaleh (JSPM) Volume 2 Nomor 1 Tahun 2021 
Dalam berbisnis produk unggulan merupakan salah satu pendekatan yang dapat diterapkan untuk peningkatan daya saing dengan menghasilkan jenis produk yang beragam. Lokal atau lokalisasi dikonotasikan dengan suatu area yang relatif terbatas, dimana pemanfaatan sumberdaya alam, manusia, sosial, fisik, dan teknologi dapat diterapkan lebih intensif dan interaktif untuk meningkatkan kegiatan produksi dan perekonomian. Usaha industri roti kering merupakan salah satu usaha berbasis industri kecil. Proses kegiatan industri tersebut sudah dilakoni cukup lama, sampai saat ini masih berjalan, dan sudah menghasilkan dua jenis produk unggulan. Produk unggulan yang dihasilkan berbeda dengan produk usaha daerah lain. Usaha industri roti kering Gampong Tingkeum Manyang memiliki dua jenis produk unggulan yaitu roti kacang dan roti kelapa.

Dalam prosesnya, produk roti kering tersebut memiliki cara pengolahan yang sama, yang membedakan hanya bahan bakunya saja. Pemilihan bahan menjadi prioritas utama, sebab bagus atau tidaknya kualitas bahan baku berpengaruh terhadap hasil roti. Dalam proses produksi bahan baku utama dicampur sedemikian rupa dengan bahan baku penolong sehingga menghasilkan suatu produk. Bahan baku utama dan bahan baku penolong tidak dapat dipisahkan karena tanpa adanya bahan baku penolong maka bahan baku utama tidak dapat diolah dengan baik sehingga tidak tercipta suatu produk. Oleh karena bahan baku sebagai pemicu utama dalam proses kegiatan produksi, maka harus dipilih dan dipilah bahan baku yang berkualitas.

Untuk roti kelapa bahan yang digunakan berupa campuran kelapa yang sudah diparut halus, sedangkan untuk roti kacang berupa kacang tanah yang sudah dihaluskan pula. Pemilihan kelapanya sendiri tidak boleh kelapa yang sudah terlalu tua karena teksturnya yang kasar sehingga menghasilkan roti yang kasar pula. Untuk bahan baku seperti kelapa dibeli langsung dari masyarakat seharga Rp. 1.500 per buah. Selain dapat membantu pendapatan atau perekonomian masyarakat sekitar juga berdampak terhadap usaha roti kering karena dengan adanya harga yang murah dan kualitas terjamin maka untung atau omset yang didapatkan sedikit lebih besar dibandingkan dengan harga pasar yaitu Rp. 2.000 atau Rp. 2.500 per buah. Untuk pembelian sekaligus sebanyak 50-70 kelapa dengan total pengeluaran biaya Rp. 100.000. Dalam sekali produksi menghabiskan 5 kelapa dan menghasilkan roti kering sebanyak kurang lebih 3-4 bal. Sedangkan untuk bahan baku seperti kacang tanah dibeli langsung dari pasar dengan harga Rp. 23.000 atau Rp. 24.000 per kilogram. Namun, karena keterbatasan modal dan kualitas dari kacang tanah yang harus terjaga supaya tidak berjamur dan kusut, maka sebagai persediaan untuk produksi selanjutnya menghabiskan pengeluaran biaya sebesar Rp. 600.000 untuk 20-25 kilogram kacang 
tanah. Dalam sekali produksi menghabiskan 1 kilogram kacang tanah dan menghasilkan 3-4 bal roti kering.

Harga suatu produk juga menentukan keberhasilan suatu usaha, mahalnya harga produk atau barang maka sedikit pula peminat dari barang tersebut. Harga roti kering produksi Gampong Tingkeum Manyang Rp.8.000 per pack dengan jumlah isi 12 bungkus roti kering. Untuk 1 bal terdiri dari 25 pack roti kering dengan harga Rp. 200.000.

Pemerintah Kabupaten Bireuen dalam memberdayakan usaha ekonomi produktif masyarakat khususnya usaha industri roti kering menghimbau kepada para pelaku usaha untuk mampu menjaga kualitas bahan agar menghasilkan produk yang maksimal. Pelaku usaha jangan meniru kebiasaan masyarakat pada umumnya, apabila suatu usaha sudah maju maka kualitas bahan baku produknya mulai dikurangi, baik itu dari segi rasa maupun bentuknya yang semakin tipis dan kecil. Pemikiran tersebut seringkali menjadi penghambat dalam mewujudkan usaha yang maju, meskipun mereka berpikir dengan tindakan tersebut dapat meraih keuntungan besar. Namun realitas yang terjadi cara tersebut tidak membuat suatu usaha yang sudah dirintis lama semakin meningkat tetapi malah semakin merosot dan mengalami berbagai problematika.

\section{Analisis Kegagalan Pemberdayaan Masyarakat}

\section{a. Produksi Roti Kering dan Akses Pemodalan}

Produksi semestinya menciptakan nilai tambah secara efektif dan seefisien. Dalam suatu produksi diperlukan adanya faktor produksi yang merupakan sumber daya potensial yang digunakan dalam kegiatan produksi agar menghasilkan barang atau jasa. Faktor produksi antara lain modal dan tenaga kerja (Setiawan \& Prajanti, 2011). Proses mengubah bahan baku menjadi barang jadi atau menambah nilai guna suatu produk dengan memanfaatkan sumber daya alam, sumber daya manusia, dan sumber daya modal sebagai sarana untuk menghasilkan barang, dan keahlian atau keterampilan untuk mengkoordinasikan dan mengelola produksi dalam menghasilkan barang yang berkualitas.

Setiap barang yang diproduksi dan kemudian dipasarkan tentu akan memperoleh hasil atau omset. Maka hasil atau omset itulah yang akan dijadikan sebagai putaran modal untuk memproduksi kembali barang tersebut. Artinya banyak atau sedikitnya laku barang akan berpengaruh terhadap omset untuk memproduksi kembali barang atau produk pada tahap selanjutnya. Berdasarkan hasil penelitian, observasi, dan wawancara menunjukkan bahwa usaha industri roti kering Gampong Tingkeum Manyang mengalami penurunan produksi. Hal ini 
disebabkan oleh permodalan. Modal yang semakin berkurang dan merosot sehingga sulit mengembangkan dan meningkatkan kembali produksi roti kering.

Modal usaha memiliki pengaruh besar terhadap produksi. Semakin tinggi modal usaha yang digunakan maka produksi pun semakin meningkat. Modal berupa uang yang digunakan untuk mengelola dan membiayai kegiatan produksi setiap bulan atau per sekali produksi dimana didalamnya terdapat ongkos untuk pembelian sumber-sumber produksi yang digunakan untuk memproduksi suatu output tertentu dan menggunakan input yang sudah tersedia. Artinya modal sebagai penunjang utama bergeraknya suatu usaha.

Pemerintah Daerah telah memfasilitasi usaha roti kering pada tahun 2015 dengan pemberian sejumlah modal usaha sebesar Rp.5.000.000 dengan metode pengembalian cicilan bunga $0 \%$. Modal tersebut digunakan untuk melengkapi sarana dan prasarana seperti oven, alat penyemprot untuk pemberian warna pada roti kering, dan lain-lain. Namun pada tahun selanjutnya (tahun 2016) roti kering produksi Gampong Tingkeum Manyang mengalami penurunan produksi karena modal tersebut tidak terjaga dan terkontrol dengan baik, sehingga berdampak kepada jumlah produksi yang semakin merosot.

Jumlah produksi sangat menentukan berkembang dan berjalannya suatu usaha. Jumlah produksi yang meningkat membuat suatu usaha lebih leluasa berkembang dan menjadikannya usaha besar serta adanya peluang-peluang untuk menumbuhkan unit-unit usaha baru. Jumlah produksi yang semakin menurun membuat usaha tersebut semakin terpuruk dan menimbulkan dampak negatif terhadap kelangsungan usaha. Usaha industri roti kering Gampong Tingkeum Manyang pada tahun 2019 jumlah produksi masih bertahan pada 95 bal-100 bal per bulannya. Hal ini menyebabkan usaha industri roti kering tidak lagi maksimal dalam menumbuhkembangkan produksinya.

Hal tersebut juga berdampak terhadap pendapatan yang didapatkan oleh pekerja usaha roti kering. Pendapatan yang semakin sedikit menjadi alasan sebagian pekerja untuk berhenti bekerja. Terkait dengan pendapatan yang didapat berbeda-beda karena ada dari pekerja yang tidak bekerja seharian penuh karena sedang menempuh pendidikan. Pendapatan ditentukan berdasarkan lamanya waktu kerja dan seberapa banyak ia membungkus atau mengepak roti kering dan juga seberapa banyak roti yang diproduksi. Dengan demikian usaha roti kering tersebut tidak hanya menjadi tempat atau mata pencaharian untuk ibu-ibu saja, tetapi juga sebagai tempat bagi anak-anak sekitar untuk mengisi waktu luang. Maka sangat diharapkan usaha roti kering tersebut dapat terus mempertahankan kelangsungan kegiatan usahanya sebagaimana yang telah dirumuskan dalam tujuan-tujuan sebelumnya, yakni menciptakan pendapatan bagi masyarakat sekitar. 
Pendapatan merupakan hasil yang didapat setelah lamanya waktu kerja. Pendapatan berpengaruh besar terhadap banyaknya jumlah para pekerja, usaha yang mengalami penurunan produksi maka juga berdampak terhadap pendapatan yang didapatkan oleh pekerjanya. Pendapatan yang sedikit menjadi alasan para pekerja untuk berhenti bekerja di indutri roti kering Gampong Tingkeum Manyang, seperti yang disampikan oleh Nurlaili, pemilik usaha industri roti kering Gampong Tingkeum Manyang berikut ini:

"Produksi yang semakin menurun otomatis pendapatan yang didapat oleh pekerja juga menurun, pendapatan yang sedikit menyebabkan pekerja tidak cukup memenuhi kebutuhan. Untuk saat ini pendapatan yang didapat oleh pekerja rata-rata berkisar antara Rp. 5.000 Rp. 20.000 per hari tergantung roti yang dibuat atau diproduksi dan lamanya waktu kerja." (Gampong Tingkeum Manyang, 14/12/2019).

\section{b. Produktivitas Kerja dan Persaingan}

Salah satu faktor yang mempengaruhi tingkat keberhasilan suatu usaha adalah produktivitas kerja. Produktivitas merupakan hasil kerja secara kualitas dan kuantitas yang dicapai oleh pemilik usaha maupun pekerja dalam melaksanakan tugas. Manusia sebagai sumber daya paling vital dalam ruang lingkup usaha. Sumber daya manusia menunjang suatu usaha dengan tenaga, bakat, dan ideide kreativitas yang dimilikinya. Betapapun sempurnanya sumber daya keuangan dan teknologi yang dimiliki, tanpa sumber daya manusia yang berkualitas maka suatu usaha tersebut sulit mencapai tujuan.

Produktivitas kerja adalah kemampuan menghasilkan barang atau jasa dan berbagai sumber daya dan kemampuan yang dimiliki oleh setiap pekerja. Produktivitas kerja mencakup sikap mental yang selalu mempunyai pandangan kehidupan mengenai pelaksanaan produksi didalam suatu usaha dimana produksi hari ini diharapkan akan lebih baik dari kemarin. Setiap orang akan selalu berusaha untuk melakukan perbaikan-perbaikan dalam pekerjaannya agar hasilnya menjadi lebih baik. Selain itu, produktivitas adalah ukuran mengenai apa yang telah dihasilkan oleh seseorang dengan hasil yang maksimal baik dalam kualitas, kuantitas, maupun waktu. Terkait dengan kemampuan dalam menghasilkan roti kering, produktivitas kerja merupakan salah satu faktor kunci dalam keberhasilan dan peningkatan usaha, yakni bagaimana menciptakan inovasi-inovasi atau keterampilan dalam menghasilkan produk yang berkualitas.

Berdasarkan hasil observasi dan wawancara menunjukkan bahwa usaha industri roti kering Gampong Tingkeum Manyang digeluti oleh masyarakat setempat merupakan salah satu potensi kewirausahaan yang bermanfaat bagi masyarakat sekitar. Salah satu faktor penyebab lain belum tercapainya peningkatan produksi usaha roti kering selain permodalan adalah pemasaran roti kering 
yang kurang laku di pasar atau daerah sendiri. Roti kering Gampong Tingkeum Manyang lebih banyak dipasarkan di daerah luar seperti Takengon ketimbang dipasarkan di daerah sendiri. Pemasaran untuk daerah sendiri juga ada namun lebih sedikit karena adanya roti kering produksi daerah lain. Proses pemasaran dan penjulan roti tersebut dilakukan dengan cara sudah adanya agen yang mengambilnya setiap hari ke rumah (tempat produksi roti kering). Agen kemudian menawarkan produk roti kering tersebut ke warung atau kios.

Kurangnya pangsa pasar di daerah sendiri ini berkenaan dengan kemampuan atau produktivitas kerja. Produktivitas pekerja maupun pemilik roti kering dalam menghasilkan roti masih kurang maksimal. Hal ini dapat dilihat dari kurangnya minat konsumen terhadap permintaan roti kering. Pengolahan roti yang kurang terampil berpengaruh terhadap hasil roti yang diproduksi.

Usaha roti kering Gampong Tingkeum Manyang mengalami berbagai macam permasalahan yang berakibat fatal bagi kelangsungan usaha. Lebih lanjut, seperti yang disampaikan oleh Ibu Nurlaili, pemilik usaha industri roti kering Gampong Tingkeum Manyang, terkait permasalahan lain yang dialami oleh usaha industri roti kering selain permasalahan modal adalah persaingan:

"Selain kekurangan modal, usaha indusrti roti kering mengalami penurunan produksi adalah adanya persaingan. Bersaingnya para penjual yang sama-sama menghasilkan produk serupa dan berusaha mendapatkan keuntungan, pangsa pasar, dan jumlah penjualan. Dalam kaitannya dengan produk roti kering ini yaitu menyebabkan roti kering Gampong Tingkeum Manyang kurang laku di daerah sendiri.” (Tingkeum Manyang, 14/12/2019).

Adanya inovasi-inovasi yang dapat menggugah minat konsumen dengan menciptakan berbagai macam bentuk dan aneka rasa roti dengan membuat, menciptakan, dan mengolahnya dengan hasil yang maksimal, tidak hanya tujuan mencari keuntungan semata tetapi juga sebagai pemuas konsumen. Produktivitas dalam menghasilkan roti jika dilihat dan dinilai dari tingkat kematangan roti masih terdapat roti dengan tingkat kematangannya yang tidak sama rata, artinya produktivitas atau kemampuan dalam menghasilkan roti masih kurang telaten.

Proses pengolahan roti kering tersebut seperti pencampuran atau pengadukan bahan dilakukan sendiri oleh pemilik usaha. Tugas pekerja hanya pada bagian pencetakan, pengovenan, dan pengemasan. Penyadaran dan peningkatan produktivitas kerja oleh Dinas Tenaga Kerja, Transmigrasi, dan Perindustrian Kabupaten Bireuen sebagai rencana strategis untuk membantu perekonomian masyarakat sekaligus mewujudkan usaha masyarakat daerah yang maju dengan melakukan pembinaan dengan tujuan untuk mewujudkan masyarakat yang berdaya, terampil, kreatif, dan inovatif. Penyadaran akan pentingnya peningkatan produktivitas kerja berarti bahwa masyarakat secara keseluruhan menjadi sadar bahwa mereka mempunyai tujuan-tujuan dan 
masalah- masalah dalam usahanya. Sehingga mereka dapat merubah pola dari yang sebelumnya ke pola yang lebih baik untuk ke depannya. Masyarakat yang sadar akan menemukan peluang-peluang dan memanfaatkannya, menemukan sumberdaya-sumberdaya yang barangkali belum pernah dipikirkan orang lain dan mampu merumuskan kebutuhan-kebutuhan dan aspirasinya.

Jumlah produksi sangat menentukan berkembang dan berjalannya suatu usaha. Jumlah produksi yang meningkat membuat usaha lebih leluasa berkembang dan menjadikannya usaha yang besar. Jumlah produksi yang semakin menurun membuat usaha tersebut semakin terpuruk dan menimbulkan dampak negatif terhadap kelangsungan usaha. Usaha industri roti kering Gampong Tingkeum Manyang mengalami penurunan produksi akibat dari permasalahan baik dari faktor internal maupun eksternal, seperti yang disampaikan oleh Nurlaili pemilik usaha industri roti kering Gampong Tingkeum Manyang berikut ini:

"Produksi roti kering meningkat dari tahun 2013-2015 nyaris membuat saya sukses dalam mengembangkan usaha ini. Namun pada tahun selanjutnya mengalami penurunan produksi, jumlah produksi untuk saat ini antara 95 bal-100 bal per bulan. Hal ini menyebabkan usaha industri roti kering tidak maksimal lagi dalam menumbuhkembangkan hasil produksi." (Wawancara 14 Desember 2019).

Hasil wawancara dan observasi menunjukkan salah satu penyebab belum mencapainya peningkatan produksi roti kering Gampong Tingkeum Manyang selain pemodalan dan pemasaran roti kering yang kurang laku di pasar atau daerah sendiri adalah minimnya inovasi dan kreativitas, seperti yang disampaikan oleh Eliya Novita, S.T, Kepala Seksi Industri Kecil Menengah dan Kerajinan Dinas Tenaga Kerja, Transmigrasi dan Perindustrian Kabupaten Bireuen:

“Tingkat kreativitas oleh industri roti kering Gampong Tingkeum Manyang masih kurang. Seharusnya usaha industri roti kering Gampong Tingkeum Manyang dapat lebih kreatif dalam mengolah bahan baku dengan cara menciptakan berbagai macam bentuk dan aneka rasa roti kering agar dapat menarik minat konsumen." (Wawancara, 16 Desember 2019).

Kepala Bidang Perindustrian Dinas Tenaga Kerja, Transmigrasi dan Perindustrian Kabupaten Bireuen, Azhar, S.E mengatakan mengenai pemberdayaan dalam meningkatkan produktivitas kerja. Produktivitas kerja merupakan aset bagi suatu usaha dalam meningkatkan produksi, menumbuhkembangkan usaha sehingga terjaminnya kelangsungan usaha yang dapat menumbuhkan unit-unit usaha baru. Sebesar apapun sumber daya yang dimiliki baik itu alam maupun sumber daya manusia dan teknologi, namun tanpa adanya keahlian sebagai modal utama maka tidak akan tergeraknya suatu usaha, seperti disampaikan:

"Kita sudah melakukan pemberdayaan terhadap usaha industri roti kering Gampong Tingkeum Manyang. Pemberdayaan ini kita lakukan demi kemajuan usaha industri di 
daerah serta untuk kesejahteraan masyarakat itu sendiri. Artinya pihak dinas ikut berpartisipasi untuk kelancaran usaha masyarakat, namun itu semua dikembalikan kepada masyarakat karena maju mundurnya suatu usaha tercatung cara masing-masing mengendalikannya." (Wawancara, 16 Desember 2019).

\section{KESIMPULAN}

Pergantian kepemimpinan sudah lama terjadi di Dinas Tenaga Kerja, Transmigrasi dan Perindustrian Kabupaten Bireuen. Hal ini berdampak pada keberlanjutan program pemberdayaan usaha industri roti kering di Gampong Tingkeum Manyang. Maka salah satu potensi yang dapat didayagunakan adalah keberadaan dana desa. Gampong Tingkeum Manyang dapat membuat program pemberdayaan sendiri dengan memberikan akses pemodalan yang memadai agar produktivitas, kreativitas, dan inovasi dapat dikembangkan guna bersaing di pasar yang semakin kompetitif.

\section{DAFTAR PUSTAKA}

Adi, I. R. (2008). Intervensi Komunitas: Pengembangan Masyarakat sebagai Upaya Pemberdayaan Masyarakat. Jakarta: PT. RajaGrafindo Persada.

Adnan, M. A. (2017). Straregi Dinas Perindustrian dan Perdagangan dalam Peningkatan Daya Saing UKM di Kecamatan Polewali Kabupaten Polewali Mandar. Jurnal Ilmu Pemerintahan dan Ilmu Komunikasi 2(2).

Aisyah, T., Alfiady, T., \& Fauzi, F. (2014). Evaluasi Program Nasional Pemberdayaan Masyarakat Mandiri Perdesaan (Studi di Kecamatan Sawang). Lhokseumawe: Unimal Press.

Arifah, T. (2011). Strategi Pengembangan Industri Kecil Jamur Tiram di Kecamatan Jambu Kabupaten Semarang. Skripsi. Universitas Negeri Semarang.

Dewi, R., Ibrahim, Z., \& Alfiady, T. (2015). Pembangunan dan Pemberdayaan Masyarakat. Jurnal Suwa, 13(3), 283-296.

Evi, R. (2001). Usaha Industri dan Kerajinan di Indonesia. Jakarta: Mutiara Sumber Widya.

Gaspersz, V. (2005). Ekonomi Manajerial: Penerapan Konsep-Konsep Ekonomi dalam Manajemen Bisnis Total. Jakarta: PT. Gramedia Pustaka Utama.

Kuncoro, M. (2006). Ekonomi Pembangunan (Teori, Masalah, dan Kebijakan). Yogyakarta: UPP STIM YKPN.

Maisyura, M., Mardhiah, A., \& Hafni, N. (2019). Pemberdayaan Masyarakat Kelompok Tani melalui Teknologi Pembuatan Pupuk Kascing. BAKTIMAS: Jurnal Pengabdian pada Masyarakat, 1(2), 114-119.

28 | Jurnal Ilmu Sosial dan Ilmu Politik Malikussaleh (JSPM) Volume 2 Nomor 1 Tahun 2021 
Mardikanto, T., \& Soebianto, P. (2012). Pemberdayaan Masyarakat dalam Perspektif Kebijakan Publik. Bandung: Alfabeta.

Nanda, R. (2018). Strategi PT. Pupuk Iskandar Muda terhadap Pemberdayaan Industri Kecil dan Menengah. Skripsi. Universitas Malikussaleh.

Setiawan, A. B \& Prajanti, S. D. W. (2011). Analisa Efisiensi Penggunaan Faktor-Faktor Produksi Usaha Tani Jagung di Kabupaten Grobongan Tahun 2008. Jejak 4(1), 69-75.

Soetomo (2006). Strategi Pemberdayaan Masyarakat. Yogyakarta: Pustaka Pelajar.

Sufi, S. (2020). Evaluasi Program Perikanan terhadap Peningkatan Nilai Produksi Ikan Asin Teri di Kota Lhokseumawe (Studi Kasus di Dinas Kelautan, Perikanan, Pertanian dan Pangan Kota Lhokseumawe). Negotium: Jurnal Ilmu Administrasi Bisnis, 3(2), 96-119.

Siti Ikramatoun, Khairulyadi, \& Riduan. (2020). Pemberdayaan Masyarakat melalui Pengelolaan Hutan Pinus di Kecamatan Linge Aceh Tengah. Jurnal Sosiologi Agama Indonesia (JSAI), 1(3), 238-249. https://doi.org/10.22373/jsai.v1i3.804

Sugiyono (2005). Memahami Penelitian Kualitatif. Bandung: Alfabeta.

Suharto, E. (2005). Membangun Masyarakat Memberdayakan. Bandung: Refika Aditama.

Sulistiyani, A. T. (2004). Kemitraan dan Model-Model Pemberdayaan. Yogyakarta: Gava Media.

Sumodiningrat, G. (2003). Pemberdayaan Masyarakat dan Jaringan Pengaman Sosial. Jakarta: Gramedia Pustaka Utama.

Usman, S. (2003). Pembangunan dan Pemberdayaan Masyarakat. Yogyakarta: Pustaka Pelajar. 